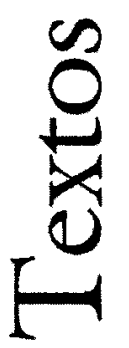




\section{Corpo humano: mercadoria ou valor?}

\section{GIOVANNI BERLINGUER}

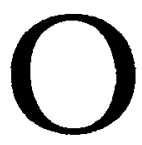

convite do Instituto de Estudos Avançados da USP é uma boa oportunidade de cotejar as orientaçōes bioéticas entre uma experiência do Norte e uma do Sul, entre duas ópticas que podem até ser convergentes, mas que hoje se encontram muito afastadas. Nos países mais desenvolvidos, a Bioética - disciplina que cuida dos temas morais da vida material - está quase exclusivamente voltada para os problemas nascidos nas zonas de fronteira entre as ciencias biológicas e médicas, tais como pesquisas e intervençóes no genoma, reprodução artificial da vida, transplantes de células e órgãos, eutanásia, ou boa morte. Óptica esta predominante, mesmo em uma publicação antológica, promovida pela Organizaçáo Pan Americana de Saúde - OPAS (Schotte Connor \& Fuenzalida-Puelma, 1990), com o propósito de oferecer visáo continental do debate bioético.

Diante da unilateralidade nortista, que ignora, por exemplo, as mortes más, prematuras e evitáveis, que persistem e talvez estejam se agravando no hemisfério Sul (e também no que se poderia chamar de Sul interno, existente em quase todos os paises desenvolvidos) diante da insistência em mirabolantes perspectivas de bem-estar oferecidas pela ciência, enquanto a vida material de grande parte do mundo torna-se cada vez mais dramática (Berlinguer, 1991) entende-se a reação de um estudioso de Bioética, o argentino José Alberto Mainetti: "La óptica de América Latina seria de olvidar todo esto, y concentrar los esfuerzos para combatir el hambre y las enfermedades más difundidas".

Compreendo tal atitude, mas não seria correto limitar-se a tanto. As promessas e os riscos nascidos nas zonas de fronteira das ciências biológicas e médicas nos envolvem a todos, não somente pela novidade e profundidade dos temas morais que devem ser encarados quando o homem se torna, em certa medida, criador de vida, mas também porque as forças que se defrontam neste campo (ciência, leis, informaçöes, mercado) assumem hoje dimensáo e comportam impacto internacionais e imediatos. Isso requer, em contrapartida, polêmica, integraçáo entre culturas e exigências que denominei - e reconheço, de modo impreciso e precário - do Norte e do Sul. 


\section{Vida, ciência e mercado}

Quanto a essa dimensáo internacional, encontrei várias informaçóes nestas semanas de permanência no Brasil, como professor visitante do Instituto de Estudos Avançados. O próprio tema de que hoje estou tratando, em particular, está presente, sob várias formas, não só no debate científico-filosófico, mas também nos noticiários do país. Gostaria de citar três exemplos.

O primeiro, está justamente em Estudos Avançados, a revista deste Instituto, que em seu último número publicou o discurso sobre as biotecnologias, proferido por Frederico Mayor, diretor-geral da UNESCO, na Cumbre Iberoamericana de la Ciencia y Tecnología (Mayor, 1992:728). Nesse discurso há vasta informaçáo sobre as perspectivas abertas pela biotecnologia referente a saúde humana, criação de animais, plantaçóes, desenvolvimento econômico. Confesso, porém, que há nesse discurso dois aspectos que me causaram dúvidas.

Um deles é que as palavras de Frederico Mayor são, acima de tudo, um hino às capacidades das biotecnologias para a soluçáo dos problemas sociais do mundo. Numa única página, ao final do texto, aparecem as preocupaçóes, os problemas éticos levantados por cientistas, personalidades culturais e políticas dos países desenvolvidos, e mais ainda do Terceiro Mundo. O exemplo mais evidente dessa tendência acrítica é a certeza, manifestada pelo autor (p.25-26), de que a modificação do genoma pode permitir a prevençáo de "las enfermedades hereditárias (causantes el $\mathbf{3 0 \%}$ de la mortalidad infantil) y las dolencias en las que la herencia tiene un papel importante, como la diabetes, el asma, las alergias, los reumatismos, la enfermedad de Alzheimer, la obesidad y las enfermedades cardiovasculares y los cánceres".

Essa frase contém uma inexatidão grosseira, devida a quem forneceu ao Sr. Mayor os dados sobre a mortalidade infantil. De fato, as causas genéticas desse fenômeno ficam muito longe dos $30 \%$, até mesmo em países desenvolvidos, e no Terceiro Mundo nem chegam a $3 \%$. Mas a frase contém ainda séria deformaçăo cultural, uma acentuaçăo de fatores genéticos, que certamente existem, mas não têm papel exclusivo na origem de doenças como as reumáticas e cardiovasculares, ou de condiçōes como a obesidade. Uma prova ex iupantibus (decorrente das melhoras) é que o índice de mortalidade infantil decresceu, neste século, de mais de 200 a cada 1000 nascimentos, para 100 ou 50, em quase todos os países do mundo, chegando a menos de 10 por 1000 naqueles mais desenvolvidos. Isso, sem que haja mudado a constituiçáo genética da humanidade; o que mudou, onde quer que se tenha progredido, 
foram as condiçóes de natalidade, economia, moradia, instruçăo, higiene, serviços sanitários. Outra prova ex iuvantibus é que nos Estados Unidos e em outros países a mortalidade por doenças cardiovasculares, principalmente por infarto do miocárdio, foi reduzida à metade nos últimos vinte anos, sobretudo após o reconhecimento dos fatores de risco (stress, desnutrição, sedentarismo, hipertensăo, fumo) e reduçăo desses fatores, sem que tenha mudado, em tão pouco tempo, a constituição genética da populaçáo. Tudo isto não diminui o valor do projeto genoma, cuja finalidade é o mapeamento integral do DNA humano, mas confirma o risco de que nele se tenda a enfatizar demais os fatores genéticos da doença com relaçáo a fatores ambientais, educação e comportamentos individuais. Alimenta-se, assim, a ilusão de que a futura terapia genética possa substituir tanto a prevençăo das doenças quanto outras terapias desde já disponíveis e eficazes.

Outro aspecto preocupante naquele discurso provém da notícia que o National Institute of Health, dos Estados Unidos, apresentou em 1991 " una primera solicitud de patentes para 347 secuencias parciales del ADN humano", e em 1992 "hizo una nueva solicitud relativa a 2375 secuencias suplementares" (p.17). Tais seqüências são comuns a qualquer ser humano, e fico profundamente perturbado ao saber que alguém apresentou "solicitud de patente" de certa porçáo, ainda que por ora mínima, de minbas células, das células de vocts, ou seja, que alguém possa vir a declará-las propriedade particular e exclusiva. Isso ofende minha intimidade e meu sentido de justiça. Perturba-me também a atitude assumida pelo Sr. Mayor perante o fato de que "se ha dirigido un llamamiento a la UNESCO para que elabore una convención internacional que permita proteger el genoma humano contra toda patentabilidad" (p.18). Isso significa, traduzindo o idioma diplomático típico das organizaçōes internacionais, que não se poderá falar concretamente do assunto antes do próximo século, quando todas as seqüências de nosso genoma já estiverem patenteadas e quando já nenhuma parte de nós pertencer a nós mesmos.

O segundo exemplo refere-se ao fato de as patentes das espécies vivas receberem, neste momento, a atençáo do Congresso, da imprensa e da televisão, no Brasil, levantando acirradas polêmicas. A Sociedade Brasileira para o Progresso da Ciência, em um de seus documentos, ressaltou que, no tocante a essas patentes, "a exceção dos EUA, a questão das plantas e animais é controvertida em todos os países" e manifestou muitas restriçóes à proposta de introduzir as citadas patentes (Jornal da USP, 1993). Posição análoga foi assumida por Dom Lucas Moreira Neves, cardeal-arcebispo de Salvador e primaz do Brasil: "Julgo altamente inconveniente tratar do patenteamento dos-microorganismos na 
mesma lei em que se trata do patenteamento dos minerais e seres inanimados. Proponho que se transfira a normatização da relação homemseres vivos para outro diploma legal, cercado de todas as cautelas relativas a seres detentores da vida (...) Patente para a vida ou seres vivos? Năo, obrigado. Já trazem uma patente inscrita na sua essência. A do Criador. A de Deus" (OESP, 1993).

Sem pretender ser blasfemo, não estou certo de que Deus haja patenteado, com a criação, todos os seres vivos. Essa idéia poderia corresponder aos conhecimentos e orientaçoóes da ciência em vigor até o século XVIII, quando o grande naturalista Lineu classificou todas as espécies animais e vegetais entáo conhecidas e afirmou que correspondiam "às que Deus quis no instante da criação". No século seguinte Darwin demonstrou que, pelo contrário, novas espécies se formam continuamente no processo de evolução. Acho, portanto, que seria um enorme trabalho para quem está lá em cima ter de atualizar continuamente o elenco das patentes. Talvez eu discorde, no plano científico-religioso, de Dom Lucas Moreira Neves. Mas a vida, seja fruto da criação divina ou da evolução natural, seja produto do caos ou da ciência, não pode ser patenteada. Eu também digo: "Não, obrigado".

O terceiro exemplo tem menos autoridade que os anteriores no plano científico e moral, mas demonstra o impacto na opinião pública do tema de que tratamos - O corpo bumano: mercadoria ou valor? Contaram-me que este ano duas telenovelas transmitidas no Brasil apaixonaram a opinião pública: uma denominada Barriga de aluguel, tratava das mães substitutas; outra, intitulada De corpo e alma, abordava como tema, os transplantes.

Não pude vê-las. Mas assisti a outras telenovelas brasileiras, que tiveram sucesso e ampla circulaçăo na Europa. Um dos lugares e dos tempos mais característicos dessas novelas, se estou bem lembrado, é o fim da escravidão no Brasil do século passado. O que me perguntei foi: haverá diferenças ou analogias entre o mercado de corpos humanos, difundido naquela época, e o mercado atual, que abrange as sequiências de DNA, os gametas, os aparelhos reprodutores; os embrióes para uso experimental, o sangue, a medula, os órgãos para transplante? Formulando um juízo moral, eu responderia que não há diferença substancial. Há diferença, isto sim, de objeto, porque no primeiro caso a compra-evenda dizia respeito ao corpo in toto, e nos outros casos o corpo é subdividido em partes e funçóes distintas, cada qual agora utilizável, seja para fins louváveis, de caráter terapêutico ou científico, seja, ao mesmo tempo, para fins comerciais. Há também uma diferença de procedimento: a organização do mercado de escravos era somente brutal; séus pro- 
motores e intermediários empregavam sobretudo a força, ao passo que o mercado atual requer a intermediaçáo da ciência biológica e da medicina profissional. Sem tal colaboração não poderia subsistir. Para essas atividades são necessários centros altamente aparelhados e profissionais com elevada especialização.

A ciência biológica e a medicina profissional assumem, portanto, uma responsabilidade particular. Neste campo, ambas enfrentam um dilema de ordem moral, pois os mesmos conhecimentos e técnicas que podem ser fator de bem-estar humano, que permitem utilizar gametas e sangue de pessoas vivas ou órgãos de pessoas mortas a fim de vencer a esterilidade e as doenças (isto é, para criar ou salvar vidas), podem também transformar o corpo humano e cada uma de suas partes em objeto, posto à venda e comercializável, como qualquer outra mercadoria.

A ciência biológica e a medicina profissional contribuíram, neste século, junto a outros fatores (como o reconhecimento dos direitos dos trabalhadores, das crianças e das mulheres) para um processo de valorizafão do corpo bumano, que atingiu, ainda que em diferente medida, todas as classes e todos os indivíduos. A corporalidade material do homem, elevada pela cultura grega a alta dignidade - por meio da arte e do exercício físico -, havia também passado por tempos obscuros, quando a Igreja medieval entendia que a humilhação do corpo era meio de elevação do espírito, ou quando as fábricas, nos primórdios da Revolução Industrial, exploravam os corpos até esgotar-lhes todas as capacidades e funçóes.

Em nosso século os direitos do corpo se firmaram na legislaçáo e nos costumes. $O$ desejo de conhecer e aprimorar a corporalidade, a aspiraçáo à saúde, à plenitude das capacidades físicas, e até mesmo à beleza, tornaram-se traços característicos do homem e da mulher de nossos tempos. Podem ser discutiveis as formas e os objetivos desses anseios. As interferências, os embustes e os excessos que acompanham tal valorização muitas vezes são criticáveis. Mas, o que há, no fundo, é uma tendência à auto-realizafão, à afirmação de si. Uma das espécies mais elevadas dessa realizaçáo, coincidente com a solidariedade para com os outros, consiste na possibilidade de transferir para o corpo alheio uma parte de nosso próprio corpo (em vida, por meio do sangue e dos gametas; após a morte, por meio dos órgãos) a fim de vencer a esterilidade, tratar de uma doença, prolongar uma vida. Esse procedimento constitui um dos fenômenos mais positivos de nossa época, para cuja afirmaçāo contribuem as ciências biológicas e as profissōes da área da saúde. Essas mesmas habilitações, porém, podem fazer com que o corpo seja rebaixado à condição de mercadoria. 


\section{A compra-e-venda de órgãos}

Minha exposição concentra-se no mercado de órgãos. Não é o único exemplo, mas, juntamente com o mercado de sangue (diferenciado por ser imediatamente reproduzível, quando racionalmente coletado) é o mais difundido, mais conhecido e também o mais significativo sob os aspectos ético, jurídico e científico.

O mercado de órgãos existe em muitos países (Berlinguer \& Garrafa, 1993:217-234). Existe na Itália, e foi descoberto graças a um acidente comercial. Dez pacientes de moléstias renais, sujeitos a diálise devido à gravidade de seus casos, impossíveis de serem tratados de outra forma, viajaram para a Índia, onde conseguiram o transplante de órgãos comprados através de agências especializadas. $O$ transplante foi executado em clínicas destinadas a tal atividade. De volta à Itália, tiveram de ser hospitalizados, por estarem sofrendo de doenças infecciosas, transmitidas através dos órgāos adquiridos de fornecedores, mal submetidos a uma inspeção de sanidade. Esse mercado existe no Brasil, onde aparecem com frequiência nos jornais, nas páginas destinadas a anúncios comerciais, ofertas de rins postos à venda. Ė verdade que a Constituição brasileira, uma das mais avançadas do mundo no campo de saúde, proíbe expressamente o comércio de sangue e de órgãos. Mas se há quem ofereça, é evidente, isso quer dizer que também há quem compre e quem faça o transplante desses órgãos. Esse mercado foi detectado na Inglaterra, onde ocorreu um processo (que terminou com a condenaçăo dos cirurgiōes e o cancelamento de seus registros médicos) devido à compra e transplante dos rins de quatro cidadãos turcos, em favor de quatro cidadãos ingleses. $\mathrm{O}$ mercado existe em muitos outros países, mas com uma constante característica: os órgãos sempre são retirados de pessoas pobres, e utilizados em pessoas ricas, de países ricos. Não há qualquer exemplo em sentido contrário (Garrafa, 1992:24-29).

Uma vez que o Instituto de Estudos Avançados não é lugar apropriado para o noticiário policial, e sim sede de sérias discussões culturais, não insistirei na exposição de tais fatos. Mas sáo eles que, de alguns anos para cá, me vêm preocupando. Nestes últimos tempos fiquei ainda mais apreensivo e surpreso, ao ler em alguns livros, e em artigos publicados em revistas científicas e filosóficas, argumentos que tendem a justificar tal mercado.

Eu acreditava que por toda a parte muitos reconhecem o princípio religioso da sacralidade do corpo, e muitos outros, ainda, o princípio jusnaturalista dos direitos naturais de todos os indivíduos, a começar pelo mais elementar: o direito à integridade e intangibilidade do corpo. Eu 
acreditava que, ao ver retirada e vendida uma parte do corpo de qualquer ser humano, todos ficassem tomados de forte emoçáo, de uma daquelas emoçōes que, por não serem efêmeras nem superficiais, mas por representarem a síntese de toda uma experiência de vida, assumem elevado valor ético (Scarpelli, 1993:22). Eu acreditava que alguns princípios da ética de Kant se houvessem tornado patrimônio comum de nossa cultu$\mathrm{ra}$, entre os quais a distinção, por ele enunciada, entre pessoa e propriedade: "O homem não pode dispor de si mesmo, porque não é uma coisa; nem é propriedade de si mesmo, pois seria contraditório. De fato, na medida em que ele é pessoa, ele é sujeito, ao qual pode caber a propriedade de outras coisas. Mas se fosse propriedade de si mesmo, seria uma coisa, cuja posse poderia reivindicar. Ora, ele é pessoa, o que é diferente de propriedade, e portanto não é coisa cuja posse lhe caiba reivindicar, pois é impossivel ser, ao mesmo tempo, coisa e pessoa, e fazer coincidir o proprietário e a propriedade. Baseado nisto, o homem não pode dispor de si mesmo. Náo lhe é permitido vender um dente ou um pedaço de si mesmo" (Kant, 1991:189).

$\mathrm{Li}$, entretanto, que um dos maiores expoentes da Bioética norteamericana, Engelhardt Jr., sustenta a moralidade da venda (e, portanto, da compra) de órgãos de pessoas vivas. "É possível que certas interpretaçóes do princípio de beneficência e certos pressupostos de fato acerca do risco de exploraçăo de indivíduos levem a crer que a venda de órgãos dará resultados moralmente indesejáveis. Mas as liberdades gerais de associaçăo e de uso dos recursos particulares devem proteger tais práticas sob o aspecto moral, embora conflitantes com os postulados gerais dos costumes ocidentais (...) Já que vender-se livremente a outrem não implica em violação do princípio de autonomia, essas trocas, baseadas em tal princípio, devem ser abrangidas pela esfera protegida da privacidade dos indivíduos livres. Além disso, se alguém se vender por preço justo e em condiçóes adequadas, supōe-se que seja possível levar ao máximo o saldo ativo de benefícios em face dos prejuízos" (Engelhardt, 1991:417-418).

Náo sei quais seriam as condiçōes adequadas, nem como estabelecer-se-ia o prefo justo, por exemplo, de um rim humano, que pesa somente de 120 a 150 gramas, mas que desempenha funçóes vitais essenciais. A doutrina econômica não nos ajuda no cálculo, e tampouco a literatura. Nesta, é verdade, há um caso que apresenta algumas analogias: refiro-me a $O$ Mercador de Veneza, de William Shakespeare. Como se sabe, o usurário Shylock pede como penhor a Antonio, fiador de três mil ducados tomados em empréstimo por seu fraterno amigo Bassanio, o direito a um saque bem definido. "Uma libra exata de vossa bela 
carne, que será cortada e tomada a parte de vosso corpo que me aprouver". Bassanio não quer que Antonio aceite por amizade o contrato, mas Shylock o tranqüiliza. Não sejam desconfiados, diz ele, o contrato é mera formalidade simbólica, eu não posso ter interesse material nesse tipo de saque. "Uma libra de carne humana, tirada do corpo de um homem, não tem sequer o valor e a utilidade de uma libra de carne de carneiro, de boi ou de cabra".

É verdade que hoje, desde que passou a haver transplantes, menos de meia libra de carne humana (ou seja, um rim) vale muito mais que um animal inteiro, mas quem a vende recebe um pagamento baixíssimo. É difícil estimar a equivalência cambial entre o antigo ducado veneziano, a moderna rúpia hindu e o dólar. Mas se fosse possível o cálculo, receio que hoje um rim valesse muito menos que o ouro de três mil ducados. Em Calcutá, por exemplo, a operaçáo completa de transplante custa cerca de 30.000 dólares, mas o fornecedor do órgáo recebe somente dez por cento: o resto vai para a clínica, para os cirurgiōes, para os intermediários. O usurário Shylock, personagem imaginária, tornou-se um dos símbolos universais da cobiça humana, mas parece-me que sua figura empalidece diante dos protagonistas desse mercado.

Entendo, porém, que deveríamos examinar com muita seriedade ao menos um dos argumentos invocados por seus adeptos. Sells, em Transplantation Proceedings (1989:1391), escreveu o seguinte: "The cause of this new market is always stated to be a deficiency of cadaveric organs". Isto é um fato real. A existência de um desequilíbrio, atualmente crescente, entre a exigência de órgãos para transplante e sua disponibilidade imediata ou, como dizem alguns, entre oferta e procura é uma realidade. Foi calculado, em números, os quais embora imprecisos não ficam longe dos dados verdadeiros, que morreram a cada ano ao menos 20.000 pessoas, que teriam oportunidade de salvar-se, e às vezes até de sobreviver por muitos anos, se encontrassem órgãos disponíveis nas condiçóes, lugares e momentos adequados.

Diante de tal fato, decerto é possível dizer: há cem mil vezes mais pessoas no mundo que morrem de fome ou de doenças infecciosas, produzidas e agravadas em condições de miséria. Mas essa objeção não tem conteúdo moral, ou o tem somente em função de outras opçóes. Os números podem, ou melhor, devem servir de guia para estabelecer prioridades sociais e para definir políticas de saúde, com base em dados epidemiológicos e em função dos interesses da maioria da populaçáo. Mas não podem valer como princípio ético, porque cada vida humana é diferente de outra e tem valor absoluto. 
Pode surgir ainda outro reparo: no caso da grande maioria dos doentes que hoje precisam de transplante, seria possível evitar essa necessidade, se houvessem sido tomadas medidas preventivas, sociais e pessoais, ou se socorros mais oportunos e eficazes tivessem sido prestados. Pode-se dar o exemplo do reumatismo, que muitas vezes provoca graves endocardites e nefrites, ou da doença de Chagas, que causa miocardites, doenças evitáveis e tratáveis, mas que muitas vezes arruínam o coração e os rins a ponto de somente restar o transplante como solução. Mas também essa objeção não tem conteúdo moral aplicável ao caso específico. A opção de concentrar recursos na prevenção e nos tratamentos básicos, mais que nas terapias reparadoras dependentes de alta tecnologia, obedece a princípios científicos e éticos, é até mais eficaz e menos dispendiosa. Mas năo pode servir de resposta válida, seja no plano moral, seja no plano prático, às pessoas para as quais o transplante representa a única possibilidade de vida.

O problema prático e moral, portanto, persiste integralmente. $\mathrm{O}$ desequilíbrio entre necessidade e disponibilidade imediata de órgãos é um fato. E quais são suas causas? Muitos se perguntam: há fạlta de órgãos ou de doadores? Todos, infelizmente, precisam reconhecer outra realidade: o que falta não são cadáveres. Sobretudo cadáveres de jovens, cujos órgãos transplantáveis muitas vezes se acham em perfeitas condiçōes, quer se trate de mortes prematuras por doença quer se trate, o que é mais freqüente, de mortes pela violência de acidentes ou de crimes.

Assim, os órgãos existem, e há também tendência crescente às doaçóes. A doação que fiz há muito tempo, quando me inscrevi na AIDO - Associação italiana de doadores de órgãos, já não tem validade prática por motivos de idade. Essa doação - conto o caso de passagem - deu-me um dos exemplos mais estranhos de bumor negro involuntário. É que, quando enviei minha ficha de inscrição, recebi da AIDO um opúsculo, endereçado a mim e intitulado: "Instruçóes que devem ser seguidas em caso de morte". Olhei o folheto com certa perplexidade e depois decidi seguir à risca, por disciplina de associado, o que ali estava escrito, a partir do título. Remeti, portanto, minha resposta, assegurando que, após o infausto evento, eu leria e aplicaria rigorosamente as instruçóes contidas no folheto.

As doações existem e podem ser multiplicadas, desde que haja estímulos e desde que todos possam comprovar e reconhecer a existência de duas garantias. Uma delas é que haja verificação objetiva da morte cerebral, isto é, que a morte não seja declarada por interesse (contra isso as leis exigem que o óbito seja atestado, com critérios severos, por médicos estranhos àquela equipe $\mathrm{e}$ à instituição que poderiam usar os órgãos 


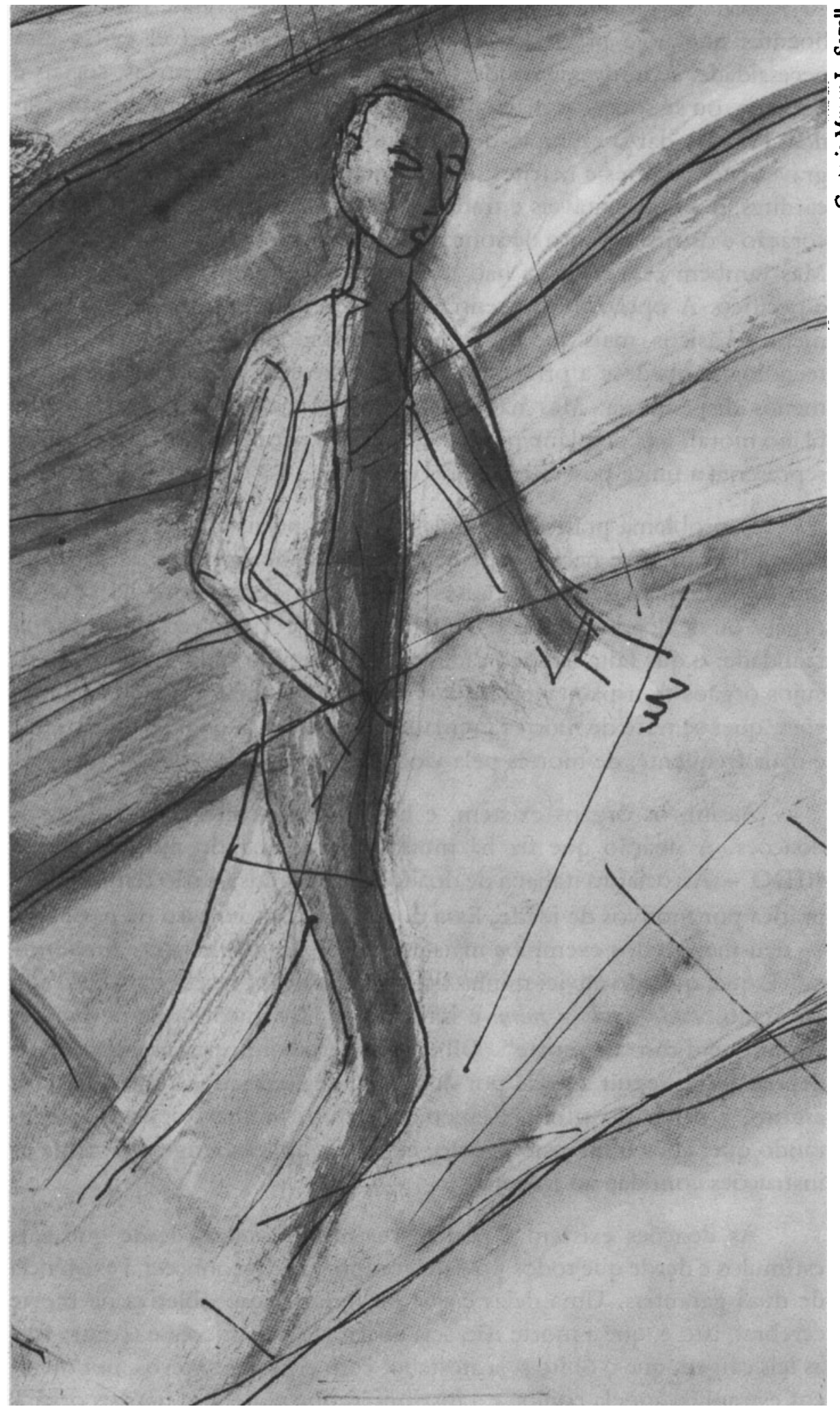

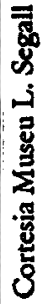

Detalhe de Homem na montanha, 1955, de Lasar Segall 
retirados do cadáver), nem antecipada (como aconteceu em alguns hospitais, segundo o noticiário), ou provocada (como ocorreu em um hospital psiquiátrico argentino). A outra garantia refere-se a que a atribuiçăo de órgãos (salvo o caso de doação feita em vida, o que seria admitido somente entre parentes próximos) náo obedeça a privilégios, amizades, avaliaçóes subjetivas da maior ou menor utilidade social de cada doente, mas a critérios de justiça. Examinando as orientaçōes legislativas latinoamericanas para os casos de transplante, escreveu Fuenzalida-Puelma (1990:70): "If the public perceives the distribution policy as unfair or contrary to important social values, it will be reluctant to donate organs. There is a general agreement that the primary criteria should be medical, and that the two main criteria should be medical need and probability of sucess".

É certo, portanto, que as doaçōes, com essas garantias e promoçáo adequada, podem ser multiplicadas. Mas persiste o desequilíbrio entre necessidade e disponibilidade imediata de órgãos, o qual, neste momento, tende a ser agravado. Multiplicam-se, portanto, as propostas destinadas a resolver o problema: algumas são realistas, outras me parecem aberrantes e extravagantes.

\section{A bioética justificativa}

Entre essas últimas propostas, a mais original é a exposta pelo filósofo inglês John Harris: organizar uma loteria universal para sortear, em caso de necessidade, quem deve fornecer, em vida, os órgãos necessários aos transplantes (Harris, 1975). O filósofo demonstrou, assim, que é o quarto escritor inglês (se é quie não me esqueço de algum outro) a encarar, em estilo de humor negro ou ironia macabra, mas sempre de modo original e criativo, a relação corpo-mercadoria em face dos desequilíbrios entre recursos e exigências, entre oferta e procura, e diante do valor de uso e de troca de nossos órgăos.

O primeiro desses escritores, em ordem cronológica, foi Shakespeare, já citado. O segundo foi Jonathan Swift, no terrivel opúsculo intitulado Modesta proposta para impedir que os filhos pobres da Irlanda onerem seus pais e seu pais, e para torná-los uiteis à comunidade. O que se dizia então é que havia um desequilíbrio entre o excesso de nascimentos de crianças e os meios que havia para alimentá-las. A fim de resolver o problema, Swift fez esta proposta: "Das cento e vinte mil crianças já recenseadas, vinte mil podem conservar-se para reprodução, e deste número somente um quarto de machos, quantidade maior à que reservamos entre ovelhas, porcos e bois. As cem mil remanescentes, logo ao 
atingirem um ano podem ser oferecidas à venda a pessoas de qualidade e posses em todo o reino, contanto que sempre se avisem as măes que as deixem mamar à vontade no último mês, a fim de torná-las gordas e rechonchudas para uma boa mesa". Fantasia macabra? Os que se opōem, por princípio, a qualquer tipo de transplante, e que, por se oporem a isso, criaram em vários paises associaçōes contra os predadores de órgũos, condenam os transplantes em bloco e os definem como sendo moderna forma de canibalismo. Esses opositores intransigentes por enquanto são pouco numerosos, porque as pessoas sabem distinguir a utilidade humana das distorçóes mercantis que existem nesse campo. Receio, porém, que tais opositores fizessem muitos prosélitos, e que qualquer tipo de transplante encontrasse crescente hostilidade, se pessoas de qualidade e posses, numerosas em todo o reino do Ocidente, fossem autorizadas a comprar órgáos, transformando-os em comida, tal qual Swift propunha acerca dos lactentes.

O terceiro foi Donald Gould (1987), com o artigo Death by decree. Hoje, ao contrário dos tempos de Swift, o desequilíbrio parece consistir no excessivo número de pessoas de idade avançada, que, com suas pensōes, representam um custo, oneram suas famílias, adoecem com freqüência, ocupam leitos hospitalares, em resumo, criam inúmeros inconvenientes à sociedade. Era de esperar que da inesgotável fonte dos escritores ingleses brotasse alguma sugestáo alternativa à de transformar velhos em comida (sugestão, como se sabe, pouco praticável, pois carne velha é dura $e$, posta à venda como comestível, valeria pouco). A proposta de Gould é simples: "Ao completar 75 anos, por exemplo, cada qual deveria receber do serviço de saúde um envelope com o aviso de que teria de se dirigir ao departamento de eutanásia do bairro, na quartafeira seguinte, às $2: 30 \mathrm{~h}$ da tarde. Ficariam isentos dessa obrigação algumas categorias de cidadáos, como ex-deputados, bispos, lordes, cientistas da Royal Society, portadores da Ordem do Mérito, membros da família real, ex-presidentes de organizaçóes sindicais e empresariais, diretores e proprietários de grandes jornais nacionais. Com isso, não só se estimularia a ambição e o sucesso (dos quais depende a continuaçáo da prosperidade nacional), mas se tornaria mais fácil a aprovação das leis necessárias."

A proposta, já conhecida como Loteria de Harris, embora pareça razoável, năo teve muito sucesso e é provável que justamente por não ter previsto as tais exceçóes, ou outras equivalentes. Em lugar de aceitar correçóes, que comprometeriam sua inspiraçăo igualitária, Harris formulou uma nova proposta: a de admitir o comércio de órgáos, assegurando-lhe a lisura através de um monopsonio (em grego, opsonion signi- 
fica provisão de víveres; monopsônio seria a concentração da procura em um só adquirente), que na Grä-Bretanha poderia ser gerido, como estrutura mais idônea, pelo National Health Service - NHS (Harris, 1993:38-39).

Digo desde já que não pretendo interferir nas opçōes da Gră-Bretanha, nem discutir as capacidades monopsônicas do National Healtb Service. Quero aventar, porém, meu receio de que, a prosseguir seu desmantelamento ao ritmo imposto pela $\mathrm{Sr}^{\mathrm{a}}$ Thatcher e seus sucessores, em breve a única tarefa atribuída pelo Estado àquela entidade será o monopsônio de órgáos; e acrescento que recearia ainda mais se a aplicaçáo do sistema se estendesse a outros países, que têm normas às vezes mais rígidas, mas serviços muito menos eficientes e seguros.

Concordo também quanto ao fato de a compra poder parecer (mas somente parecer) o meio mais rápido e econômico de se obter órgãos com a finalidade de transplante. Na verdade, uma vez superadas todas as barreiras morais, o meio mais rápido e econômico seria roubálos. Talvez isso introduzisse na sociedade elementos de desordem que poriam em discussáo a vigência organizada das leis de mercado, caso os roubos se disseminassem a outros setores.

Acrescento que a compra de órgãos, até agora quase sempre feita por países ricos em países pobres, representaria um elemento de continuidade de antiga tradiçāo que, sem isso, estaria arriscada a desaparecer. De fato, o bem-estar do Ocidente há muitos séculos vem sendo alcançado não só pelo exercício de capacidades e aptidóes próprias, mas também pela busca de recursos em outras partes do mundo. Primeiro, ouro da América; depois, escravos da África (que se viam desenraizados sem pagamento algum, ao passo que o fornecedor de órgãos recebe uma retribuição, ainda que mínima); a seguir, algodão e matérias-primas da Ásia. E assim por diante. Agora, pergunta Paul Kennedy (1953), o que podem oferecer os países pobres ao mercado mundial? Mão-de-obra barata? É o que hoje acontece, mas seu valor será diminuído pela revolução dos autômatos: robôs construirão robôs, como o Japão já começou a produzir, e essa produção custará menos do que empregar trabalhadores do Terceiro Mundo. Alimentos e produtos vegetais? Ainda são exportados, mas a revoluçăo biotecnológica e a engenharia genética permitiráo produzi-los de outras formas, e diminuirá muito o valor da agricultura das lavouras tradicionais. A única produção que ainda prossegue em ritmo acelerado no Sul do planeta é outra: a produçăo de populaçóes humanas. E já que os órgãos humanos por ora năo se mostram substituíveis por outros produtos (discutirei depois esta afirmação), e são objetos de crescente procura, aí está um campo em que se pode assegurar por 
decênios, talvez por séculos, a continuidade histórica de espoliação. Senão, corre-se o risco de interrompê-la, porque já não sabemos de que recursos dos pobres lançar mão para nosso bem-estar.

Postas estas premissas, sublinho uma diferença essencial entre as sugestóes de Harris (e de outros filósofos e cirurgióes que tendem a legalizar a compra-e-venda de órgãos) e as invençóes de seus citados predecessores, Shakespeare, Swift e Gould. Essas invençóes eram, justamente, invençōes literárias, ao passo que as sugestōes de Harris e outros baseiam-se em fatos já ocorridos. As invençōes literárias provocam somente fantasia, e até influem favoravelmente, com o poder que tantas vezes têm os paradoxos, a fim de conduzir a maior respeito para com nossos semelhantes. As sugestóes citadas podem desencadear apetites canibais, ao reconhecerem a moralidade intrínseca do mercado de órgãos, e limitam-se a propor-lhe regulamentação, por meio de tabelamento de preços ou de delegação a instituiçōes respeitáveis.

Parece-me poder dizer que tais afirmaçōes assinalam, se não o nascimento, o apogeu de uma nova corrente da Bioética. Até aqui eu conhecia tendências personalistas, utilitaristas, contratualistas e outras baseadas na teoria dos direitos; outras, ainda, fundadas em doutrinas religiosas e filosóficas laicistas. Agora nasceu a Bioética justificativa, que se dá conta do que existe, considerando-o, por isso mesmo, conforme à lei ética. Por outras palavras: tudo o que é real é não só racional, mas também moral.

Como toda a corrente que nasce e não pode limitar-se a usar as palavras preexistentes, por serem insuficientes e até embaraçosas às novas idéias, a Bioética justificativa já vem revelando forte fantasia, ao criar expressóes verbais que absolvem e legitimam o mercado de órgáos. A venda se chama rewarded gifting (doação remunerada) e o vendedor, retparded donor (doador remunerado). Este business, em conjunto, é definido com um ato de indirect altruism (altruísmo indireto), que vem a criar um soft buman market (mercado humano suave, doce, gentil, abrandado), cujo fundamento é a existência de um bought living-unrelated donor (doador vivo, comprado e sem parentesco). Já que um órgão pode ser comprado com prorrogação de prazo de entrega, isto é, já que se pode assinar um contrato que obriga a cessáo do órgáo após a morte, é possível obter o cash benefit for binding consent to donation (compensação em dinheiro pela obrigação de consentir na doação), ou, mais sinteticamente, o cash death-benefit (compensação em dinheiro pelo óbito). Pouco importa que todas essas definiçōes modifiquem o significado comum das palavras ou criem antíteses gritantes, como as que ocorrem entre doação e pagamento, ou entre óbito e compensaçăo: a operação de 


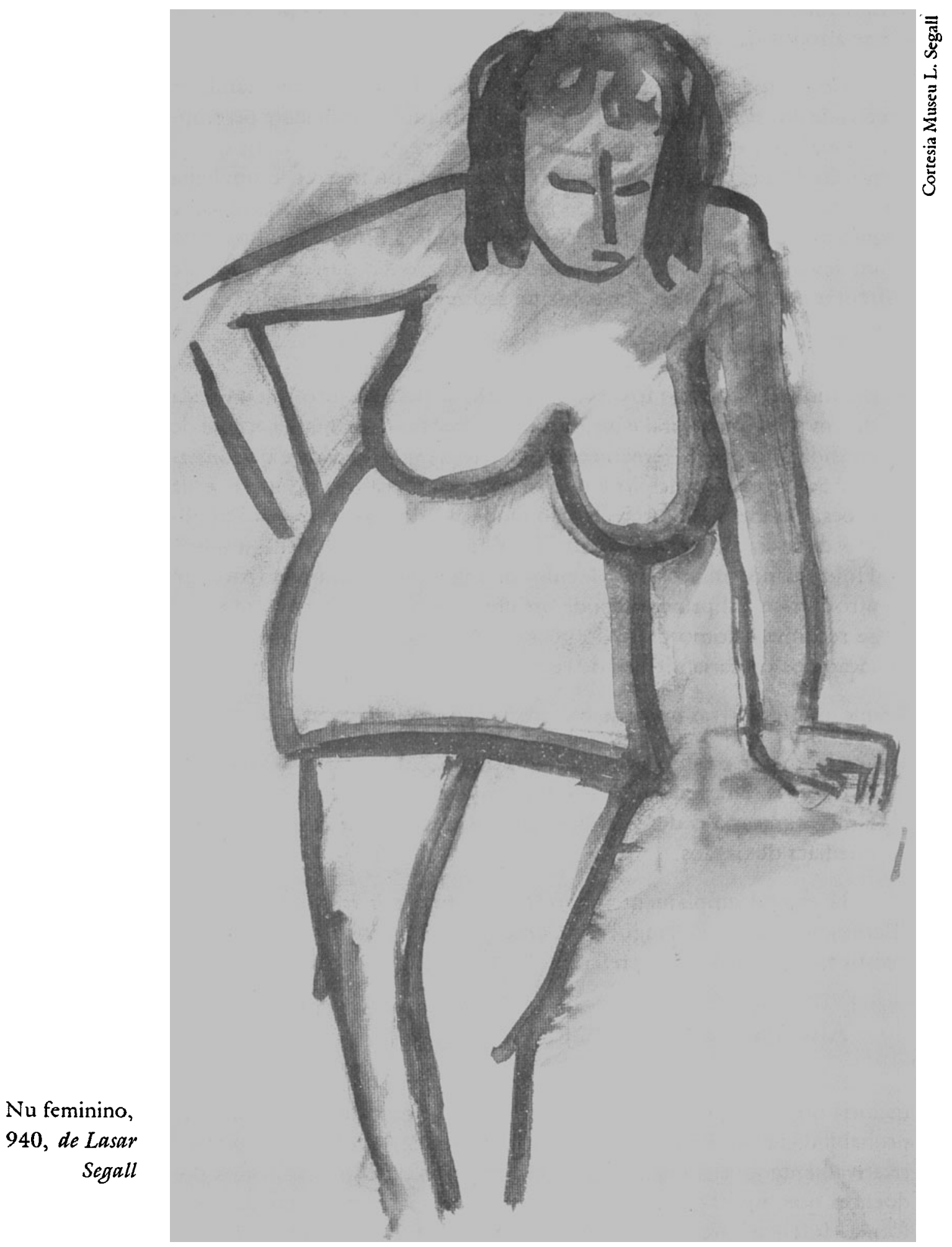


abrandamento foi legitimamente iniciada no léxico, e daqui pode expandir-se a todos os setores.

Como toda a corrente que nasce, a Bioética justificativa também precisa de um slogan sintético (se possivel, rimado!) e suficiente peremptório para fazer entender que não há rumo alternativo. Parece-me que já o encontrei na expressão to buy or to die, comprar ou morrer. É um lema que toca as cordas sensíveis do íntimo dos doentes desesperados e daqueles que, por afeição, estão dispostos a tudo a fim de salvá-los. Mas é um lema baseado no pressuposto de não haver outros modos de enfrentar o desequilíbrio que somente assim se julga superável.

Todavia, eu sustento:

- mesmo que isso tudo fosse verdade, náo se poderia justificar a queda de um princípio moral e jurídico de caráter fundamental: a recusa de considerar o corpo humano como objeto de propriedade e de comércio. Sobre esse princípio é que se constituiu, através de idéias e de açōes, grande parte da civilização moderna, do babeas-corpus à abolição da escravatura, do direito à saúde, à emancipação da mulher. Hoje, quando muitos dos vínculos de solidariedade humana parecem afrouxar-se, tal princípio pode ser uma das bases para que cada qual se reconheça como parte do gêneru humano, ao passo que sua violação nos causaria séculos de retrocesso;

- que as alternativas existem, e é preciso constituí-las;

- que legitimar e estender o mercado de órgãos levaria a desacreditar as doaçóes, lançando uma sombra em todos os transplantes e, portanto, agravaria o desequilíbrio entre necessidade e disponibilidade imediata de órgãos.

Já escrevi amplamente sobre esses temas em trabalhos recentes (Berlinguer, 1993; Berlinguer \& Garrafa, 1993); limito-me, por isso, a insistir no segundo ponto, referente às alternativas possíveis.

\section{Alternativas ao mercado de órgãos}

Antes de mais nada, pode-se atuar na vertente da procura. $\mathrm{Na}$ maioria dos casos, o transplante é solicitado (e executado com maiores probabilidades de êxito e de longa sobrevivência) em favor de pessoas relativamente jovens cujos órgáos foram precocemente arruinados por doenças que, muitas vezes, teria sido possível evitar ou tratar de outra forma. Infelizmente não existem estatísticas precisas sobre $o$ assunto. Isso, devido às pesquisas promovidas pelos que cuidam dos transplantes, 
reunidos na Transplantation Society, interessarem-se sobretudo por problemas biológicos de histocompatibilidade, técnicas operatórias e destino pós-operatório dos pacientes, deixando de avaliar o número dos que - dentre aqueles que recorrem ao implante de um órgão alheio poderiam ter evitado esse recurso se houvesse prevenção adequada, ou se tivesse sido prestado a tempo tratamento médico oportuno.

Na vertente da oferta é preciso partir do fato de que grande parte dos órgãos potencialmente disponíveis não são coletados nem utilizados, pela simples razão de faltarem comunicaçōes entre os serviços, pois neles domina a burocracia autárquica, a rivalidade, o isolamento. No tocante aos rins, os órgãos efetivamente disponíveis são: na Itália, 10 para cada milhão de habitantes; na França, 32; nos países mais organizados, até 50 e, neste caso, suficientes, por enquanto.

Considero humilhante, além de muito dispendioso, o fato de a Itália ter de recorrer a outros países para preencher um déficit de órgãos que poderia resolver com suas próprias forças. Isso năo se deve à pouca propensão dos italianos às doaçóes. No caso do sangue, por exemplo, há muito tempo existem redes de organização do voluntariado, informaçóes e solicitaçóes de doadores permanentes ou esporádicos, centros móveis e estáveis que facilitam a coleta, bancos que permitem a conservação e distribuição, comunicaçōes com os hospitais que fazem as transfusōes. No caso dos órgãos, não existe quase nada semelhante, mas uma pesquisa realizada mostra que $80 \%$ das pessoas e das famílias são potencialmente favoráveis à doação.

No Brasil, depois da transmissão da novela sobre transplante, foi observado ter duplicado o número de pessoas que se apresentam espontaneamente aos centros de transplante e subscrevem sua disposição a doar. Nos serviços que deveriam assegurar a coleta, distribuiçăo e uso de órgãos, tudo é disperso, caótico, irracional. As dificuldades burocráticas, os entraves operacionais, o desleixo de administradores e médicos muitas vezes se opóem à generosidade dos que gostariam de transformar sua própria morte, ou a morte de um parente, em possibilidade de vida para outra pessoa. Pode-se afirmar que a eliminaçáo desses obstáculos e a melhora na organização dos serviços podem representar, hoje, a fonte mais imediata e a solução que, por si só, permitiria superar grande parte das dificuldades existentes.

Deve-se acrescentar a isso, o estímulo a elevar o número das doações voluntárias, por meio de informaçóes precisas, garantias objetivas e apelos à solidariedade. Tal procedimento, porém, pode não bastar, principalmente se os transplantes (de rim, de fígado, de coração, de 
coração-pulmão e de outros órgāos) vierem a ter maior êxito em assegurar longa sobrevida às pessoas operadas, o que é previsível. Por outro lado, o sistema de doaçóes voluntárias, apesar do valor moral inerente ao ato, apresenta como problema a exigência de uma comprovação da vontade manifestada em vida pelo defunto, ou da irrestrita concordância post-mortem por parte da família. Isso, às vezes, requer prazos relativamente longos, incompatíveis com o uso imediato dos órgãos (1).

Por essa razão, em muitos países a legislação tende a passar do consentimento afirmado ao consentimento presumido, permitindo a realização da coleta como praxe normal, dispensando a decisão da família enlutada quanto ao pedido dos médicos. Tal sistema pode assegurar disponibilidade muito maior de órgãos e, em qualquer caso, muito superior à procura atual e mesmo à futura, se os serviços forem bem organizados. Entre as legislaçóes que aceitaram esse procedimento, cito como exemplo, a francesa, na qual foi prevista uma exceção: a coleta não é admitida quando a pessoa houver manifestado, em vida, restrição contra o uso de seus órgáos após a morte. O consentimento presumido, portanto, é também definido como siléncio-consenso: calar-se equivale a consentir, mas é possível opor-se, mediante explícita declaração de desacordo.

Esta exceção tem como fundamento ético o respeito à vontade individual, mas vale também para abrandar o impacto de uma norma que - é preciso reconhecê-lo - modifica profundamente uma tradição e uma cultura milenar de quase todos os povos: o culto aos mortos; não como espírito e memória, mas como corpos, destinados, segundo muitas religióes, a sobreviver ou renascer. Sob o aspecto antropológico, pode-se acrescentar ser espontâneo que qualquer um sinta, no mínimo, mal-estar diante da perspectiva de intromissão em seu cadáver e que, com isso, qualquer pessoa sofrerá ainda maior dor com as mortes em família.

Entretanto, uma idéia oposta pode prevalecer no plano dos sentimentos e das emoçóes: a de que o próprio corpo, ou o de um parente, ainda possa ser útil para outrem. E possível que se manifeste, e afinal prevaleça, uma espécie de egoismo altruista, consistente em saber que de modo diferente da continuidade de vida prometida pelas religiōes algo de cada qual sobreviverá em outros, em desconhecidos beneficiários dos órgãos. Para tanto, é indispensável informar, educar, garantir, mas também possibilitar uma declaração pessoal de recusa, sem que isso importe em acusaçóes de insensibilidade ou sentimento de culpa. Uma doaçăo imposta como obrigação seria, na linguagem e na essência, contradiçăo evidente, semelhante, análoga à chamada revparded gifting. 
No plano estritamente ético, o que se dá é um conflito de valores, cada qual com sua própria justificativa. Neste caso, o conflito se dá entre o respeitoso carinho para com o corpo de quem acaba de separar-se da família e a possibilidade de restaurar a sanidade e a vitalidade de outro corpo, irremediavelmente doente na impossibilidade do transplante. Parece-me que no plano ético não pode haver dúvidas sobre o valor preponderante. No plano jurídico, Harris sublinhou que "já existe hoje um precedente a este propósito, na atual legislação, que permite aos tribunais ordenar exames post-mortem: se hoje se admite que o interesse público de eliminar suspeitas sobre a causa do óbito é suficientemente importante para prevalecer sobre os desejos dos parentes, interessados na integridade do cadáver, então deve-se reconhecer que o interesse público em salvar milhares de vidas é, de longe, maior" (Harris, 1993:38).

A tais alternativas, baseadas no uso mais extenso e racional de possibilidades e conbecimentos existentes, podem-se acrescentar outras soluçóes, ligadas a duas promissoras linhas de pesquisas: órgãos artificiais e xenotransplantes. Nestes setores ainda estamos iniciando, até porque ambos têm sido pouco incentivados. Mas já é possivel, por exemplo, dispor de alguns componentes de sangue produzidos com DNA recombinante. Os xenotransplantes, isto é, o uso de órgãos provenientes de outras espécies mais ou menos afins já têm sido tentados, mas quase sempre com pouca seriedade, finalidades sensacionalistas e péssimos resultados para os pacientes, além de efeitos contraproducentes para esta hipótese operacional. No futuro, porém, o xenotransplante certamente será possível, sobretudo se utilizados animais transgênicos, cujos órgãos sejam compatibilizados com o organismo humano. Desde já, entretanto, vêm sendo levantadas objeções morais contra esta hipótese, fundadas nas teorias animalistas, que merecem a máxima consideração. A tais objeçōes tem sido respondido que é difícil ver diferença entre a criação de animais para alimentação humana ou para a coleta de órgãos. A essa argumentação replica-se brutalmente, mas não de modo absurdo, que do ponto de vista subjetivo é mais fácil aceitar que o porco forneça a carne para a alimentação do que o coração que se vai receber para implante. Talvez a analogia mais exata seja a que diz respeito ao uso de animais para experiências com medicamentos. Há correntes animalistas que se opóem a qualquer experiência, porém, a tendência principal, não só da ciência mais responsável, mas da opiniáo pública, orienta-se antes para a maior limitação possível e para a estrita regulamentação do uso de animais. Prevê-se, todavia, seu emprego quando a alternativa seja a de passar diretamente à experiência em seres humanos (Berlinguer, 1991) (2). 
Acredito, de qualquer forma, que os xenotransplantes podem suscitar repulsa menor que a compra-e-venda de órgãos.

\section{Conseqüências e implicações morais e práticas}

Dado que as alternativas existem, ou podem ser construídas, devemos avaliar as consequiências e implicaçóes que comportam as opçóes de legitimar e ampliar o mercado ou trabalhar pelas alternativas. Uma das duas soluçōes acarreta, ainda que não automaticamente, a exclusăo da outra. O recurso ao mercado, seja como for que se conceba e regulamente - selvagem ou monopsônico - bloqueia indiretamente outros caminhos, justamente por parecer oferecer um atalho fácil e rápido. Sabe-se há tempo, por exemplo, que acenar com retribuiçóes, a fim de obter-se o sangue necessário às transfusóes, dificulta o recurso às doaçōes espontâneas (Titmus, 1970).

No que diz respeito aos órgãos, a contradição é mais forte: não se pode recorrer ao mercado e ao mesmo tempo promover a oferta consentida em nome do bem-estar alheio, pois se os transplantes se transformarem em comércio macabro, bem poucos estarăo dispostos à doaçăo. É preciso também ponderar que tal prática implicaria em frear, ou em desviar de seus objetivos, as forças de pressão capazes de estimular a melhora na organização de serviços (os doentes e suas famílias, as associaçóes de doadores, os médicos mais conscienciosos, os administradores hospitalares mais sensíveis, os movimentos políticos e culturais de solidariedade). Raciocínio análogo vale quanto à pesquisa biomédica $\mathrm{e}$ tecnológica referentes a soluçóes alternativas, que atualmente já pode ser dirigida a órgãos artificiais e xenotransplantes: não é possível buscar, ao mesmo tempo, o trabalho de instituiçōes científicas e as especulaçōes de instituiçōes profissionais e comerciais. Em conclusão, o desequilíbrio entre necessidade e disponibilidade de órgáos correria o risco de se agravar definitivamente.

Lançando o olhar para além do tema específico, ao qual me restringi até agora, deve-se também refletir sobre as consequiências morais e práticas que ambas as opçōes comportam em todos os campos, ou seja, sobre os efeitos acarretados pela escolha de uma ou de outra solução nos campos do saber, do direito, da convivência cívica, das profissóes.

É muito provável que, se nos reportarmos ao plano geral das relaçōes econômicas e sociais, no futuro não haja, entre mercado e solidariedade, a antítese global tão nítida que os contrapôs neste dilacerado século XX. Pode-se entender que a antítese é superável nas orientaçōes culturais, no campo da produção e distribuição, no exercício da democracia. 
Mas o dilema que diz respeito ao corpo humano, a opçáo de considerálo valor em si ou mercadoria, náo é conciliável, não admite soluçōes intermediárias. É um divisor de águas moral que pode tornar-se uma das referências essenciais do comportamento humano no século XXI, em todos os campos.

Passo a referir-me ao Direito. Desde a época em que foi abolida a escravidão, em todos os países e nas normas internacionais o corpo náo é mais assimilado às coisas que se podem comprar e vender. A diferença entre sujeito e objeto tornou-se um dos pilares da cultura juridica de nossos tempos. Será que teremos de voltar atrás? Ou será que teremos de ampliar a esfera dos direitos e liberdades, promovendo um estatuto do corpo, que leve em conta os avanços e as manipulaçōes hoje permitidas pelas ciências biomédicas? O princípio da identidade biológica pessoal $\mathrm{e}$ de sua intangibilidade, por exemplo, ainda não foi reconhecido. O tema da informação, para dar mais um exemplo, assume dimensóes antes ignoradas: por um lado, há o direito a conhecer todos os dados acerca de si mesmo e também a dominar os fatores (trabalho, ambiente, desgaste) que possam influir na integridade pessoal; por outro lado, há o direito a proteger a privacidade contra comunicaçóes indevidas de notícias referentes à vida biológica pessoal (genética, saúde etc.) ou à vida social de cada um (opiniōes, hábitos, amizades, relaçōes familiares), em caso de abuso por parte de bancos de dados.

Passo a falar agora das profissóes, das referentes à área da saúde, mas de outras também. Será que elas devem transformar-se em atividades empresariais e mercantis? Ou devem manter o caráter de serviço (adequadamente remunerado e até estimulado por meio de incentivos materiais) em favor dos cidadãos? Hoje a populaçăo avalia as profissōes, sobretudo as da saúde, que empregam alta tecnologia no diagnóstico e na terapêutica, com um misto de admiração pelo que sabem fazer e de indignação pelo que lucram. Não tenho dúvida de que a indignaçáo prevalecerá, se se obtiver lucro amputando órgáos de pessoas vivas, constrangidas a vendê-los por necessidade, procedimento que lançará uma triste sombra em todas as profissóes da área da saúde. Pode-se também acrescentar que, ao contrário, se o exemplo de justiça e de correçāo for dado - como até agora em grande parte vem ocorrendo por aqueles que executam os atos operatórios mais sugestivos, que gozam quase de um halo de milagre, isso poderá refletir-se positivamente em todas as relaçóes entre médicos e cidadãos.

A seguir, refiro-me à ciência. Muitos pretendem que a Bioética somente serve para fixar limites ao desenvolvimento do conhecimento científico. Mas a ética fundamental da ciência é a liberdade. A comuni- 
dade científica é, justamente, quem tem proposto limites, não ao desejo de saber, mas aos métodos usados para satisfazê-lo. Por esse motivo, depois de serem reveladas ao mundo as pesquisas feitas por cientistas nazistas com prisioneiros dos campos de concentraçáo, foi elaborado o Código de Nurenberg, que estabelece regras experimentais fundadas no respeito ao ser humano, resultando na posterior difusão de outras normas para assegurar o respeito a todos os seres vivos. A perspectiva da liberdade, pressuposto da pesquisa científica, não é violada por tais normas, pois em qualquer campo vale o princípio kantiano segundo o qual a liberdade de cada um tem como único limite a liberdade do outro. No campo dos transplantes năo está em jogo a liberdade de pesquisa, nem sequer está em jogo outro problema ético mais complexo, a opçáo entre várias tecnologias de aplicaçáo de conhecimentos (como ocorreu na Física, quiando foi possível usar a energia nuclear para fins pacíficos ou militares, e como hoje ocorre em alguns setores da Biologia). Nem os conhecimentos básicos, nem as técnicas de aplicação dos transplantes podem beneficiar-se com operaçöes comerciais executadas com vendedores de órgãos e não com verdadeiros doadores, que estejam praticando um ato de generosidade para com seus parentes.

Três outras observaçóes podem ser acrescentadas, a propósito da ciência e das profissóes:

- os obstáculos ao avanço dos conhecimentos, surgindo não dos limites postos pela Bioética, mas das tentativas de transformar o saber em propriedade particular. $O$ requerimento de patente de seqüências do genoma humano, por exemplo, está criando obstáculos à circulaçáo dos conhecimentos e à colaboração científica internacional, que são pressupostos e princípios essenciais da liberdade da ciência;

- as leis que proíbem a compra-e-venda de órgáos (já aprovadas em muitos países, como na Inglaterra, através do Organ Transplantation Bill, na França, na Rússia e em alguns países da América Latina) não correm o risco, muitas vezes presente, de ficarem letra morta. À diferença do mercado humano da época da escravidão, exercido com métodos que não exigiam o que hoje chamamos de especialização profissional, os órgáos năo podem ser transplantados em poróes de navios nem vendido em praças públicas. $O$ transplante requer estruturas e profissóes altamente especializadas, facilmente sujeitas a registros e inspeçōes;

- uma analogia com a escravidão, porém, pode ser a ampla, e às vezes, inesgotável disponibilidade de mercadoria humana, de mão-de-obra conquistada com guerras, ou comprada e vendida, ter sido ao longo 
dos séculos, talvez de milênios, um dos obstáculos principais ao progresso da ciência e da técnici. O mesmo pode acontecer se, para enfrentarmos o problema dos recursos necessários aos transplantes, abrirmos em larga escala a possibilidade de compra-e-venda de órgãos, dificultando, assim, a pesquisa de soluçōes alternativas.

Faço também referência, sem desenvolver o assunto, à convivência cívica $\mathrm{e}$ às rclaçóes com a natureza. Será que se deve aceitar tudo poder ser comprado ou obtido com violência, seja ela brutal, seja encoberta pela riqueza? Será que tudo pode ser comprado ou roubado, sejam órgăos para transplante, sangue para transfusão, recém-nascidos para adoção ou mulheres e meninas para a prostituição? Será que tudo pode tornar-se propriedade particular do mais forte, mesmo as espécies animais e vegetais geneticamente transformadas, até mesmo as que são produto da evolução natural?

No tocante às patentes, o fato que mais me surpreende é que algumas empresas multinacionais as estejam reivindicando por terem descoberto novas plantas - em países da América centro-meridional, da Ásia ou da África - utilizáveis para fins nutritivos, industriais ou terapêuticos. Não acredito que espécie alguma das existentes na natureza possa ser patenteada, mas se isso fosse lícito, estou certo de que a patente caberia somente ao país de origem. Se fosse reconhecido valor retroativo a essas patentes, os países da América poderiam exigir, de todos os demais, royalties pela batata, pelo tomate, pelo milho, pelo quinino e por centenas de outras espécies nascidas aqui, cuja utilidade foi reconhecida e que daqui se espalharam pelo mundo. Será que para o homem e para a natureza devem valer os princípios de violência e de propriedade exclusiva, ou o princípio do respeito, da não-violência, da disponibilidade universal?

Quero falar, enfim, das relaçóes entre o Norte e o Sul do planeta, entre desenvolvimento e subdesenvolvimento, entre riqueza e pobreza. Já ressaltei, ao discorrer sobre a Bioética justificativa, que o Norte, o desenvolvimento, a riqueza, progrediram tanto por mérito de seu próprio trabalho quanto pela exploração de recursos do Sul, do subdesenvolvimento, da pobreza. Os males do Sul, do subdesenvolvimento, da pobreza, não podem ser atribuídos somente a essa exploração, sobretudo pelo que aconteceu no atual século, quando as classes oprimidas chegaram à possibilidade de tutelar seus próprios direitos. E preciso também olhar para o que fizeram e desfizeram as classes dirigentes desses países. Mas neste assunto dos males, de que agora trato, o problema não é só o da busca de responsabilidades. É outro: com a ilimitada disponibilidade de mercado dos órgãos que hoje podem ser transplan- 
tados (e amanhā, talvez, de outras partes essenciais do corpo), será que se deve criar uma conveniência vital de manter os paises subdesenvolvidos $e$ as classes pobres em condiçōes de miséria total, a ponto de a compra-e-venda de partes do ser humano poder até mostrar-se ùma vantagem recíproca imediata? Ou será que se deve trabalhar a fim de tornar conveniente para todos a busca do bem-estar comum? Isso implicaria em sair do Sul e da pobreza do subdesenvolvimento material, mas também em sair do Norte e da riqueza do subdesenvolvimento moral, que às vezes o caracteriza e que pode achar sua expressão mais exasperada precisamente na tentativa de legitimar e estender aos seres vivos e à espécie humana as leis de mercado, cuja função pode até ser positiva dentro do campo da produção.

Tive o privilégio de conhecer e frequientar um grande cientista e político brasileiro quando, durante a ditadura, esteve exilado na Europa: Josué de Castro. Com seu trabalho como presidente da FAO e com seus livros, foi ele o primeiro a fazer conhecer a geografia e a geopolítica da fome no mundo. Costumava dizer que a humanidade se dividia em dois grupos: o dos que não comem e o dos que náo dormem, de peso na consciência e, mais ainda, de medo da revolta dos famintos. Eu continuo a esperar que a ciência, a ética, o direito e a política ajudem uns e outros a encontrar o equilíbrio; que ajudem a transformar este mundo, a fim de que todos possam comer, viver íntegros e sadios, trabalhar, dormir, divertir-se, saber.

\section{Notas}

1 Sobre as dificuldades existentes a este respeito nos países da América Latina cf. o artigo de H.L. Fuenzalida-Palma, Organ transplantation: the Latin American legislative response, p.68-69.

2 Cf. G. Berlinguer, Bioetica della sperimentazione, in: Questione di vita, cit., p. 55-70.

\section{Referências bibliográficas}

BERLINGUER, G. Questioni di vita. Etica, scienza, salute. Torino, Einaudi, 1991 (Ed. em português a cargo da HUCITEC, São Paulo, 1993).

BERLINGUER, G. Salute e ambiente. Il corpo com merce o come valore. Capitalismo natura socialismo, A.III, n.l, marzo 1993.

BERLINGUER, G.; GARRAFA, V. La merce uomo, Micromega, n.1, 1993.

ENGELHARDT JR., H.T. Manuale di bioetica. Milano, Il Saggiatore, 1991. 
FUENZALIDA-PUELMA, H.L. Organ transplantation: the Latin American legislative response. In Schotte Connor, H.L. \& Fuenzalida-Puelma, H.L. (eds.). Bioetbics. Issues and perspectives. Scientific Publication n.527, Washington, Panamerican Health Organization, 1990.

GARRAFA, V. Usos e abusos do corpo humano. Sazide em debate, n.36, out. 1992.

GOULD, D. Death by decree. New Scientist, 14 maio 1987.

HARRIS, J. La biotecnologia nel 2000. Wondemvoman e Superman, n.1, 1993, p.38-39.

HARRIS, J. The Survival Lottery, Plsilosoplyy, n.4, 1975.

KANT, 1. Lezioni di etica. Bari, Laterza, 1991.

KENNEDY, P. Verso il XXI secolo (Preparing for the Twenty First Century), Milano, Garzanti, 1993.

MAYOR, F. Las biotecnologlas a principios de los noventa: éxitos, perspectivas y retos. Sevilla, 6 de octobre de 1992 (In: Estudos Avançados, São Paulo, v.6, n.16, p.7-28, 1992.

NEVES, Dom Lucas Moreira. Patente para a vida?. O Estado de S.Paulo, 21 abr. 1993.

PATENTES. Posição da SBPC. Jornnal da USP, São Paulo, 26/04 a 02/05/1993, p.3-4.

SCARPELLI, U. Etica della libertì. Biotica, n.1, 1993.

SCHOTTE CONNOR, H.L. Fuenzalida-Puelma (eds.). Bioethics. Issues and perspectives. Scientific Publication n 527, Washington, PAHO, 1990.

TITMUS, R.M. The gift relationship, 1970.

\section{Resumo}

O artigo discute algumas questōes éticas surgidas com o transplante de órgãos humanos. Tais órgăos, afirma-se, nunca devem ser obtidos por meio de negociaçōes comerciais, o que tende a reduzi-los a simples mercadoria. As doaçōes espontâneas e a pesquisa médica devem ser incentivadas a fim de minorar a falta de órgãos disponíveis para transplantes. Além disso, segundo o autor, a remoção compulsória de órgãos de cadáveres deve também ser assegurada por lei, mesmo contra a oposição da familia, salvo quando expressas instruçóes forem deixadas pelo falecido.

\section{Abstract}

This article discusses some ethical questions raised by transplantation of human 
organs. Such organs, it is argued, should never be supplied through commercial dealings, which tend to reduce human bodies to mere merchandise. Spontaneous donations and medical research should de encouraged in order to lessen shortage of organs available for transplantation. Besides, according to the author, mandatory removal of organs from corpses should also be enforced by law, even against familiar opposition, except when explicit instructions against that procedure are left by the deceased person.

Giovanni Berlinguer, médico, é professor da Universidade "La Sapienza", em Roma, e ex-senador.

Conferência do Mês do IEA-USP feita pelo autor em 28 de abril de 1993.

O original em italiano - "Il Corpo Umano: Merce o Valore?" - encontra-se à disposição do leitor no IEA-USP para eventual consulta.

Traduçāo de Pedro Garcez Ghirardi, professor de Literatura Italiana na FFLCH-USP. 